\title{
A koronária-CT bevezetésének elsö tapasztalatai a Bajcsy-Zsilinszky Kórházban
}

\author{
Czakó Balázs', Jablonkai Balázs', Tarján Zsolt², Andrássy Péter ${ }^{1}$
}

1Bajcsy-Zsilinszky Kórház és Rendelőintézet, Kardiológiai Osztály, Budapest
${ }^{2}$ Bajcsy-Zsilinszky Kórház és Rendelőintézet, Radiológiai Osztály, Budapest

Levelezési cím:

Dr. Czakó Balázs, e-mail: czako.balazs@bajcsy.hu

\begin{abstract}
A krónikus koronáriaszindróma kivizsgálása során egyre nagyobb szerepet kapnak a noninvazív anatómiai képalkotó vizsgálatok. A koronária-CT-vizsgálat magas negatív prediktív értéke és a szövődmények alacsony száma miatt kiváló eljárás a szignifikáns koronáriabetegség kizárására, a nonszignifikáns koronáriabetegség felismerésével pedig szerepe lehet a kardiovaszkuláris események megelözésében. A modalitás intézetünkben 2018 óta elérhetö. 2019 végéig összesen 217 vizsgálatot végeztünk ( $52 \%$ nő, átlagéletkor $56,7 \pm 12,7$ év), amelyek adatait retrospektíven elemeztük. A leggyakoribb indikációk között mellkasi fájdalom (67\%), terhelésre jelentkező nehézlégzés (9\%), magas kardiovaszkuláris rizikó (8\%) szerepelt. A betegek átlagos preteszt probability értéke a 2019-es európai ajánlás alapján számolva az alacsonyabb tartományba esett $(13,5 \pm 10,5 \%)$. Agatston-score alapján a betegek 25,2\%-ának nem volt koronáriameszesedése, 23,3\%-ánál minimálisan, 20,5\%-ánál enyhén, 17,2\%-ánál közepesen, 13,6\%-ánál súlyosan kalcifikált koronáriarendszert detektáltunk. CT-angiográfiát a betegek $7 \%$-ában nem végeztünk a jelentős fokú kalcifikáció miatt. Plakk $58 \%$-ban, obstruktív koronáriabetegség $24 \%$-ban került leírásra. A klinikailag indokolt esetekben szívkatéteres vizsgálat történt, amellyel, mint gold standarddal összehasonlítva a nemzetközi irodalmi adatokkal összevethető negatív prediktív értéket észleltünk (éralapú analízis esetén 96\%, betegalapú analízis esetén 100\%). A fejlödés vizsgálatának céljából az első 109 vizsgálat adatait a második 108 vizsgálat adataival összehasonlítva szignifikánsan csökkent az átlagos sugárdózis, emelkedett a prospektíven EKG-kapuzott felvételek aránya, javult a felvételek minősége. Mindezek alapján elmondható, hogy az intézményünkben végzett koronária-CT-vizsgálat a nemzetközi ajánlásoknak megfelelően használható a krónikus koronáriaszindróma diagnosztikájában.
\end{abstract}

Kulcsszavak: krónikus, koronária, szindróma, CT

\section{First experiences with coronary CT angiography in Bajcsy-Zsilinszky Hospital}

Non-invasive imaging techniques have an increasing role in chronic coronary syndrome assessment. Due to it's high negative predictive value and low rate of complications, coronary CT angiography is an excellent method for excluding obstructive coronary artery disease and, by recognizing non-significant coronary artery disease, may play a role in the prevention of cardiovascular events. In our hospital coronary CT was initiated in 2018. Since then until the end of 2019, 217 examinations were performed (female: $52 \%$, average age: $56,7 \pm 12,7$ years), the data of which were analysed retrospectively. The most common indications were chest pain (67\%), shortness of breath on exertion (9\%) and high cardiovascular risk (8\%). The average pretest probability value was in the lower range $(13,5 \pm 10,5 \%)$, based on the recent European guideline. Twenty five percent of the patients did not have, $23 \%$ had minimal, $21 \%$ had mild, $17 \%$ had moderate and $14 \%$ had severe coronary calcification. CT angiography was not accomplished in $7 \%$ of cases due to high degree of coronary calcification. Plaque was found in $58 \%$ and obstructive coronary artery disease was found in $24 \%$ of the patients. Compared to invasive coronary angiography (which was performed in the clinically reasonable cases), the negative predictive value was consistent with the values in the international literature (in vessel-based analysis $96 \%$, in patient-based analysis 100\%).To assess the development, we compared the data of the first 109 patients with the last 108 patients. We found significant reduction in radiation dose, improvement of the image quality and increase in the proportion of prospectively ECG-gated exams. In conclusion, coronary CT angiography, performed in our facility, could be appropriately used for the assessment of chronic coronary syndrome according to international guidelines.

Keywords: chronic, coronary, syndrome, CT 


\section{Bevezetés}

A krónikus koronáriaszindróma kivizsgálása kapcsán szemléletváltás történt az elmúlt években, ugyanis egyre nagyobb szerepet kaptak a noninvazív anatómiai vizsgálatok az invazív koronarográfiával szemben. Ennek hátterében több tényező áll. Egyrészt az utóbbi időben ezen vizsgálatok - különösképp a koronária-CT-angiográfiás vizsgálat - kapcsán jelentős technikai fejlődés, a diagnosztikus teljesítmény javulása volt megfigyelhető. Másrészt több klinikai vizsgálatban is megfigyelték azt, hogy az iszkémiás szívbetegség gyanúja miatt vizsgált, stabil állapotú betegekben a szignifikáns koronáriabetegség prevalenciája alacsonyabb a korábban leírtaknál, és a korábbi irányelvek alapján kalkulált preteszt valószínüségek túlbecsülik a betegség tényleges elöfordulását ezen populációban (1). Alacsonyabb prevalencia esetén pedig nagyobb szerep jut a betegség kizárását célzó, lehetőleg alacsony szövődményrátával bíró vizsgálatoknak. Ezek között szerepel a koronária-CT-angiográfiás vizsgálat is, amely jellemzője a magas negatív prediktív érték és szenzitivitás, különösen az alacsonyabb pre-teszt valószínűségek esetén (2). Így nem meglepő, hogy a koronária-CT-angiográfia indikációs köre jelentősen bővült. Nagy-Britanniában a NICE (,National Institute for Health and Care Excellence") ajánlása szerint költséghatékony, ha minden, koronáriabetegség gyanúja miatt vizsgált betegnél elsőként koronária-CT-angiográfia történik (3). Az Európai Kardiológiai Társaság ajánlása kevésbé egyértelmü, de szintén jelentős szerepet tulajdonít az említett modalitásnak a 2019-ben megjelent Krónikus Koronáriaszindróma irányelvben (4). Ezek alapján számítani lehet a koronária-CT-vizsgálatok iránti igény növekedésére, tekintve azt is, hogy az anatómiai kép mellett már funkcionális, iszkémia kimutatását célzó módszerek is léteznek, bár ezek a mindennapi gyakorlatban még nem terjedtek el.

Ezen tendenciákat tekintve intézetünkben 2018-ban elérhetővé vált a koronária-CT-angiográfiás vizsgálat. Jelen célkitűzésünk az volt, hogy az eddig elkészült vizsgálatok elemzésével bemutassuk az első tapasztalatokat, eredményeket, a növekvő esetszám melletti fejlődési ütemet.

\section{A metodika bevezetése}

Kórházunkban 2018 elején telepítettek egy 128-szeletes, koronária-angiográfia végzésére alkalmas CT-készüléket. A metodika elméleti és gyakorlati alapjainak megtanulására egy kardiológus kolléga elvégezte a Harefield CT Course 1-es és 2-es szintü tanfolyamát. A vizsgálatok Neusoft 128-szeletes CT-géppel történtek. A gép technikai paramétereinek beállításában a gyártó képviselőjén kívül segítségünkre voltak a Semmelweis Egyetem Városmajori Szív- és Érgyógyászati
Klinika, MTA-SE Lendület Kardiovaszkuláris Képalkotó Kutatócsoportjának koronária-CT-ben járatos szakemberei.

\section{Módszerek}

Osztályunkon a betegek tájékozott beleegyezése mellett az előkészítéséhez, a kívánt szívfrekvencia eléréséhez premedikációt alkalmaztunk orális metoprolol, alprazolam, ivabradin és intravénás metoprolol szükség szerinti kombinációjában. A vizsgálatok Neusoft 128-szeletes CT-géppel történtek. A topográfiai felvételeket követően minden esetben prospektíven kapuzott natív felvételek készültek a koronáriakalcifikáció megítélésére. Ezt követően megtörtént a koronária-CT-angiográfia. Amennyiben a pulzusszám engedte (szívfrekvencia <65/perc) prospektíven EKG-kapuzott felvételek készültek, egyéb esetekben retrospektíven EKG-kapuzott vizsgálatot végeztünk. Jelentős fokú koszorúér-meszesedés esetén (Agatston-score > 800-1000) angiográfiát nem végeztünk, mivel a lumenátmérők a kiterjedt, súlyos fokú kalcifikáció mellett biztonsággal nem megítélhetők (4). A leletezés, illetve a lelet felépítése a magyar (5) és a nemzetközi ajánlásoknak megfelelően történt (6).

Jelen retrospektív vizsgálatunkban, az intézményünkben 2019 végéig elvégzett koronária-CT-vizsgálatok adatait elemeztük. Adataink forrása kórházunk számítógépes rendszere volt. Vizsgáltuk a betegek demográfiai adatait (életkor, nem), anamnézisét, a vizsgálatok indikációit, a 2019-es európai ajánlás alapján számolt pre-teszt valószínüséget (pre-test probability, PTP) és a premedikációhoz használt gyógyszerek dózisát. Jellemeztük a natív felvételek alapján a koszorúér-meszesedés mértékét az Agatston-score segítségével. 0 értéknél a kalcifikáció hiányát, 1-10 között minimális, 11-100 között enyhe, 101-400 között közepes, 400 felett súlyos fokú koronáriameszesedést véleményeztünk (7). Vizsgáltuk a koronária-CT-angiográfiás felvételeken a plakk jelenlétét, lokalizációját, az obstruktív szükületek arányát (lumenátmérő szerint $>50 \%$ szükület), lokalizációját. A klinikailag indokolt esetekben történt invazív koronarográfia eredményével, mint gold standarddal, összehasonlítottuk a CT eredményét az obstruktív koszorúér-betegségre vonatkozóan, külön fő erekre (bal fötörzs (LM), bal elülső leszálló ág (LAD), bal körbefutó ág (LCX), jobb ág (RCA), intermedier ág (IM), illetve betegekre vonatkoztatva. Elemeztük a vizsgálatok technikai paramétereit (angiográfia sugárdózisa és összesített sugárdózis „dose length product”-ban - DLP - kifejezve, kontrasztanyag-mennyiség), a szövődmények arányát és jellegét. A fejlődés vizsgálatának céljából a fenti adatokat összehasonlítottuk a vizsgálatok első (1-109. beteg) és második időszakában (110-217. beteg).

A statisztikai feldolgozás során $p<0,05$ értékben hatá- 
roztuk meg a szignifikancia szintjét. A kategorikus változók analízise során khi-négyzet próbát alkalmaztunk. Folytonos változók kapcsán, normáleloszlás esetén kétmintás t-próbát végeztünk, amíg nem normáleloszlás esetén Mann-Whitney-U-tesztet.

Jelen vizsgálat elvégzésében, publikálásában a szerzőknek anyagi érdekeltsége nem volt.

\section{Eredmények}

\section{Demográfiai adatok, anamnézis}

2019 végéig összesen 217 betegnél történt koronária-CT-vizsgálat. A betegek átlagéletkora $56,7 \pm 12,7$ év volt. A nemek aránya között érdemi különbség nem mutatkozott (nők 52\%, férfiak 48\%). A páciensek kórelőzményében leggyakrabban magasvérnyomás-betegség (66\%), hyperlipidaemia (47\%) és cukorbetegség $(20 \%)$ szerepelt. Összesen 6 olyan betegnél történt vizsgálat, akiknél korábban már diagnosztizálták az obstruktív koszorúér-betegséget. Közülük 4-4 beteg korábban már szívinfarktuson, illetve perkután koronária-intervención esett át.

\section{Vizsgálati indikációk}

A leggyakoribb indikációk között mellkasi fájdalom (67\%), terhelésre jelentkező nehézlégzés (9\%), magas kardiovaszkuláris rizikó (8\%) szerepelt. A fennmaradó esetekben szívelégtelenség, palpitáció, nyugalmi EKG-eltérés, pozitív ergometria, szívmütét előtti kivizsgálás volt a beutalás indoka. A mellkasi fájdalommal jelentkező betegek csoportjában 17\%-ban típusos angina, 43\%-ban atípusos angina, 40\%-ban anginára nem típusos mellkasi fájdalom volt explorálható (1. ábra). A 2019-es, krónikus koronária szindrómáról szóló európai ajánlásnak megfelelően számolt átlagos PTP az alacsonyabb tartományba esett $(13,5 \pm 10,5 \%)$.

\section{Agatston-score}

A vizsgált populáció átlagos Agatston-score értéke 190,5 volt. A betegek $25,2 \%$-ának nem volt koronáriameszesedése, 23,3\%-ánál minimálisan, 20,5\%-ánál

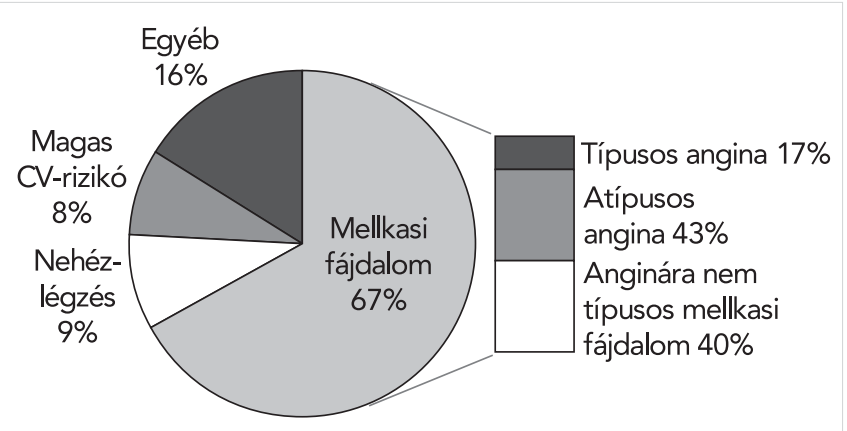

1. ÁBRA. A koronária-CT-vizsgálatra beutalt betegek vizsgálati indikációi százalékos megoszlásban. Az egyéb kategória elemei: szívelégtelenség, palpitáció, nyugalmi EKG-eltérés, pozitív ergometria, szívmütét előtti kivizsgálás

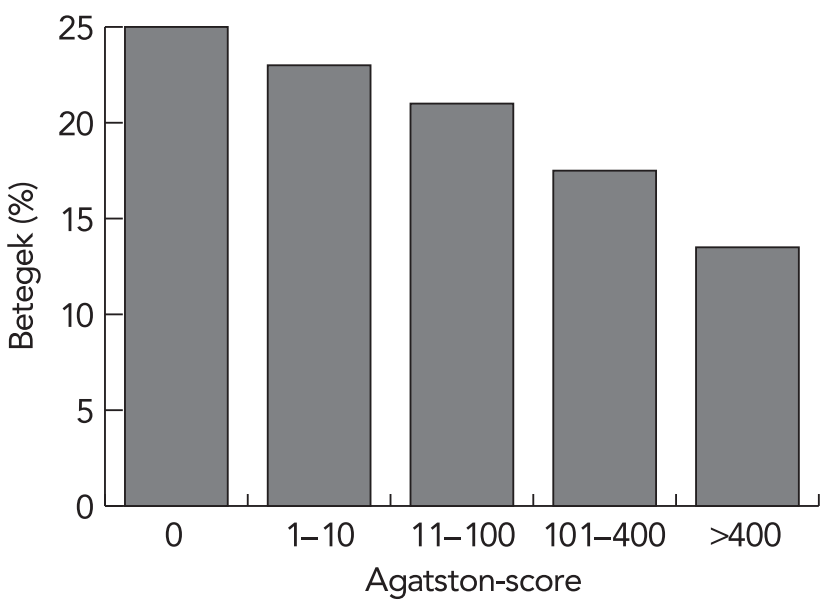

2. ÁBRA. A betegek megoszlása a koronáriarendszer meszesedésének mértékét jellemző Agatston-score alapján

enyhén, 17,2\%-ánál közepesen, 13,6\%-ánál súlyosan kalcifikált koronáriarendszert detektáltunk (2. ábra). A betegek $7 \%$-ánál olyan súlyos fokú, kiterjedt koszorúér-meszesedést észleltünk, hogy az angiográfiát nem végeztük el.

\section{Technikai paraméterek, képminőség, szövődmények}

A teljes vizsgálat átlagos sugárdózisa DLP-ben kifejezve $545 \pm 294 \mathrm{mGyxcm}$, önmagában egy angiográfia

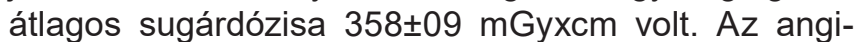
ográfiák $41 \%$-a prospektíven, $59 \%$-a retrospektíven EKG-kapuzott vizsgálatként készült el. Az összesített sugárdózis jelentősen eltért a két metódus között (432 mGyxcm vs. 671 mGyxcm, p<0,001). Az esetek 24\%ában kiegészítő angiográfiás felvételek készítésére volt szükség. A felhasznált átlagos kontrasztanyag-mennyi-

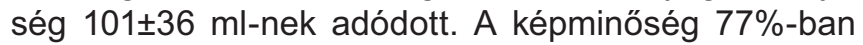
„értékelhető - jó” kategóriába tartozott, 21\%-ban „korlátozottan értékelhető”, $2 \%$-ban „nem diagnosztikus értékü" volt a vizsgálat. A betegek 2,5\%-ánál jelentkezett valamilyen szövődmény ( 2 alkalommal paravasatum, 2 alkalommal urticaria, 1 alkalommal anafilaxiás reakció), amelyek lege artis ellátásra kerültek.

\section{Koronária-CT-angiográfia eredménye}

Lefutási, eredési anomáliát összesen 2 esetben észleltünk. A betegek $58 \%$-ában detektáltunk plakkot a koszorúerekben. Ezek előfordulása leggyakrabban az LAD-ot érintette (a betegek 52\%-a), a többi koronárián ritkább volt a plakk jelenléte (RCA: $27 \%$, IM: 24\%, LCX: 22\%, LM: 19\%). Obstruktív koszorúér-betegséget az esetek 24\%-ában véleményeztünk. Az LAD-ban a betegek 18,5\%-ában, az RCA-ban 9,5\%-ban, az IMben $8 \%$-ban, LCX-ben 7,5\%-ban, az LM-ben $2 \%$-ban írtunk le szignifikáns szükületet (3. ábra). A vizsgálatot követően az esetek 31\%-ában javasoltunk invazív koronarográfiát. 


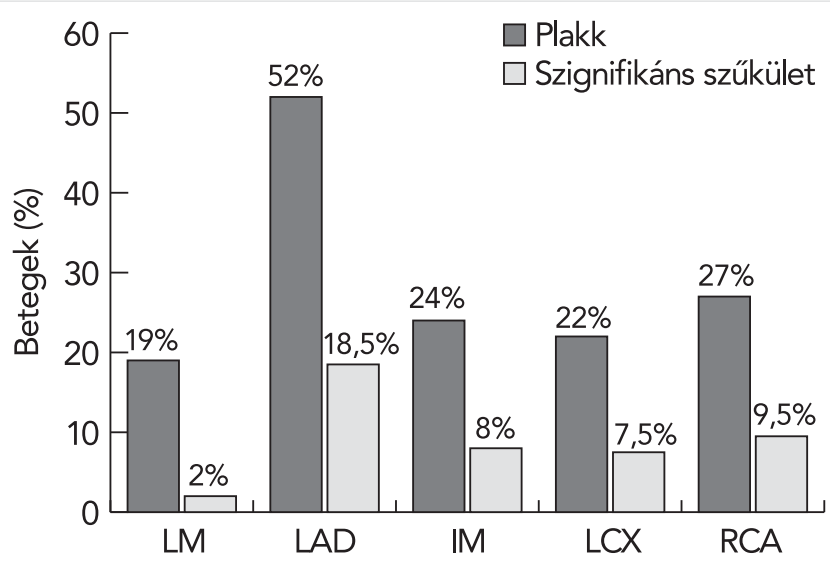

3. ÁBRA. Plakk és szignifikáns szűkület előfordulási aránya a különböző koronáriákban a koronária-CT-angiográfia alapján

\section{Diagnosztikus teljesítmény}

A koronária-CT-angiográfia eredményét összesen 41 beteg esetében tudtuk szívkatéteres vizsgálat leletéhez viszonyítani az obstruktív koszorúér-betegség vonatkozásában. $A$ betegalapú analízis során álnegatív eredmény nem volt, így $100 \%$-os negatív prediktív értéket és szenzitivitást észleltünk, alacsony pozitív prediktív érték $(57,6 \%)$ és specificitás $(36,4 \%)$ mellett. Az éralapú analízis kapcsán összesen 169 koronária vonatkozásában történt összehasonlítás szignifikáns szükület jelenlétét illetően. A szenzitivitás, specificitás, pozitív és negatív prediktív érték $87,1 \% ; 78,3 \% ; 47,4 \%$; és 96,4\%-nak adódott (1. táblázat).

\section{A fejlődés vizsgálata}

A vizsgálatok első időszakához képest a másodikban szignifikánsan emelkedett a betegek előkészítéséhez használt orális metoprolol $(64,6 \mathrm{mg}$ vs. $79,5 \mathrm{mg}$; $p<0,01)$ és ivabradin $(0,14 \mathrm{mg}$ vs. $0,78 \mathrm{mg} ; \mathrm{p}<0,05)$ dózisa. Az angiográfiák második felében jelentősen meg-

\begin{tabular}{|c|c|c|c|}
\hline $\begin{array}{l}\text { Éralapú } \\
\text { analízis }\end{array}$ & $\begin{array}{l}\text { Korona- } \\
\text { rográfia + }\end{array}$ & $\begin{array}{l}\text { Korona- } \\
\text { rográfia - }\end{array}$ & \\
\hline CT-angiográfia - & 4 & 108 & NPV: $96,4 \%$ \\
\hline \multirow[t]{2}{*}{ CT-angiográfia + } & 27 & 30 & PPV: $47,4 \%$ \\
\hline & $\begin{array}{l}\text { Szenzitivi- } \\
\text { tás: } 87,1 \%\end{array}$ & $\begin{array}{c}\text { Specificitás: } \\
78,3 \%\end{array}$ & \\
\hline $\begin{array}{l}\text { Betegalapú } \\
\text { analízis }\end{array}$ & $\begin{array}{l}\text { Korona- } \\
\text { rográfia + }\end{array}$ & $\begin{array}{l}\text { Korona- } \\
\text { rográfia - }\end{array}$ & \\
\hline CT-angiográfia + & 19 & 14 & PPV: $57,6 \%$ \\
\hline \multirow[t]{2}{*}{ CT-angiográfia - } & 0 & 8 & NPV: $100 \%$ \\
\hline & $\begin{array}{l}\text { Szenzitivi- } \\
\text { tás: } 100 \%\end{array}$ & $\begin{array}{c}\text { Specificitás: } \\
36,4 \%\end{array}$ & \\
\hline
\end{tabular}

2. TÁBLÁZAT. A fejlődés vizsgálatának céljából összehasonlítottuk a betegek első felének adatait a betegek második felével. Szignifikánsan emelkedett a metoprolol és ivabradin alkalmazott dózisa, a prospektíven EKG-kapuzott vizsgálatok aránya, javult a képminőség, csökkent a sugárdózis és a kiegészítő felvételek aránya

\begin{tabular}{|c|c|c|c|}
\hline & $\begin{array}{l}1-109 . \\
\text { beteg }\end{array}$ & $\begin{array}{l}110-217 . \\
\text { beteg }\end{array}$ & p-érték \\
\hline Metoprolol (átlag, mg) & 64,6 & 79,5 & $<0,01$ \\
\hline Ivabradin (átlag, mg) & 0,14 & 0,78 & $<0,05$ \\
\hline $\begin{array}{l}\text { Prospektíven EKG } \\
\text { kapuzott vizsgálat (\%) }\end{array}$ & 18 & 66 & $<0,001$ \\
\hline Kiegészítő felvétel (\%) & 30 & 17 & $<0,05$ \\
\hline $\begin{array}{l}\text { Teljes vizsgálati sugár- } \\
\text { dózis (átlag, mGyxcm) }\end{array}$ & 598 & 491 & $<0,001$ \\
\hline $\begin{array}{l}\text { Egy angiográfia } \\
\text { sugárdózisa (átlag, } \\
\text { mGyxcm) }\end{array}$ & 396 & 319 & $<0,001$ \\
\hline $\begin{array}{l}\text { Értékelhető vagy jó } \\
\text { képminöség }(\%)\end{array}$ & 71 & 84 & $<0,05$ \\
\hline
\end{tabular}

nőtt a prospektíven EKG-kapuzott vizsgálatok aránya ( $18 \%$ vs. $66 \% ; p<0,001)$, számottevően csökkent az átlagos teljes vizsgálatra, illetve egy angiográfiára eső sugárdózis (598 mGyxcm vs. $491 \mathrm{mGyxcm} ; \mathrm{p}<0,001$, illetve 396 mGyxcm vs. 319 mGyxcm; $p<0,001)$. Szignifikáns mértékben csökkent a kiegészítő felvételek aránya ( $30 \%$ vs. $17 \% ; p<0,05)$. A képminőség tekintetében is jelentős javulás volt megfigyelhető („értékelhető-jó” minőség aránya $71 \%$ vs. $84 \% ; p<0,05)$ (2. táblázat).

\section{Extrakardiális eltérések}

Az extrakardiális képletek elemzésével 2 beteg került kiemelésre és kivizsgálásra radiológiailag igazolt roszszindulatú tüdőtumor miatt.

\section{Megbeszélés}

Az Európai Kardiológiai Társaság 2019-es Krónikus Koronáriaszindróma irányelvében az új, alacsonyabb pre-teszt valószínüségek nem azt jelentik, hogy a betegek sokkal nagyobb hányadánál kizárható a koronáriabetegség az alapszintű vizsgálatokkal, hanem azt, hogy nagyobb szerepet kapnak a nonnvazív tesztek. 5\%-os pre-teszt valószínűség alatt érdemes elsősorban alternatív diagnózis lehetőségét mérlegelni, 5-15\% közötti valószínüség esetén bizonyos rizikótényezők figyelembevételével megfontolandó, $15 \%$ felett pedig egyértelmủen javasolt koszorúér-betegség irányú további kivizsgálás (4). Az általunk vizsgált betegek átlagos PTP-je az utóbbi két csoport határát közelíti, amely alapján a klinikai gyakorlat ilyen tekintetben összhangban van az ajánlással.

A koronáriakalcifikáció mértékének meghatározása alapvető eleme a vizsgálatnak, mert amellett, hogy gyors, egyszerü és minimális sugárterheléssel jár, iro- 
dalmi adatok szerint panaszmentes és panaszos betegek esetén is független kardiovaszkuláris rizikófaktornak tekinthető (8). Emellett az angiográfiát megelőző méréssel kiszürhetők azon nagyon meszes koronáriarendszerrel bíró betegek, akik a magas rizikó és a kalcium okozta mütermékek miatt nem profitálnának a CT-angiográfiás vizsgálatból. Ezen csoportban elkerülhetjük a fölösleges sugár- és kontrasztanyag-terhelést. Meg kell azonban jegyezni, hogy a kalcifikáció hiánya nem zárja ki plakk, illetve akár obstruktív koronáriabetegség lehetőségét (9). A CT-vizsgálatnál fontos kérdés a sugárterhelés, amely számos befolyásolható tényezőtől is függ az adott gép technikai paraméterei mellett. Eredményeinkben megfigyelhető az esetszám növekedésével párhuzamosan a sugárterhelés mértékének csökkenése, amelynek hátterében az egyre hatékonyabb betegelőkészítés és a vizsgálati beállítások optimalizálása révén az értékelhető képminőséghez szükséges kiegészítő felvételek számának csökkenése, valamint a prospektíven EKG-kapuzott felvételek számának növekedése áll. $A$ képminőség tovább javítható, és így az összesített sugár- és kontrasztanyag-terhelés tovább csökkenthető a megfelelő betegkiválasztással, amelyet a korábban említett ajánlás is részletez (4).

A vizsgálat diagnosztikus teljesítménye alapján alkalmas az obstruktív koszorúér-betegség biztonsággal történő kizárására, amely a mi eredményeinkben is megmutatkozik (magas negatív prediktív érték). A pozitív prediktív érték ettől jelentősen elmarad, hiszen a koronária-CT ismerten túlbecsüli a szűkületek mértékét, leginkább a kalcifikált plakkok esetében (10). Azonban a nonobstruktív plakkok felismerésének is jelentősége van. Ez a tulajdonság az egyéb, funkcionális noninvazív vizsgálatokkal szemben óriási előny, hiszen a nonobstruktív koronáriabetegség felismerése - a vizsgált betegek 34\%-ában találtunk szignifikáns szükületet nem okozó plakkot - segítséget nyújthat a kardiovaszkuláris események megelőzésében. Ezt támasztják alá többek között a SCOT-HEART-vizsgálat eredményei is. A stabil angina pectoris miatt vizsgált betegek közül azok, akik a standard ellátás mellett koronária-CT-vizsgálaton is átestek, nagyobb arányban kaptak preventív és antianginás gyógyszeres kezelést, illetve 5 év alatt kisebb arányban érték el az elsődleges kompozit végpontot (nem halálos miokardiális infarktus és koronáriabetegség okozta halálozás), amellett, hogy ennyi idő alatt az elvégzett invazív koronarográfiák és koronária-intervenciók számában nem volt érdemi különbség (11).

\section{Következtetések}

Összességében elmondható, hogy a koronária-CT-angiográfiás vizsgálat egyre fontosabb szerepet tölt be az iszkémiás szívbetegség diagnosztikájában és ezáltal rendkívüli módon nő az igény erre a vizsgálatra. Jelen retrospektív vizsgálatunk igazolja, hogy megfelelő előkészületek, oktatás, technikai feltételek mellett két év alatt a minőségkontrollt is elvégezve biztonsággal bevezethető egy kardiológiai centrumban a koronária-CT-angiográfiás vizsgálat.

\section{Köszönetnyilvánítás}

A Bajcsy-Zsilinszky Kórház koronária-CT-angiográfiás vizsgálatainak bevezetéséhez nélkülözhetetlen technikai és elméleti támogatást kaptunk Maurovich-Horvat Pál, Szilveszter Bálint és Kolossváry Márton kollégáinktól. A módszer rutinszerü bevezetésében gyakorlati segítséget adott Nagy Balázs CT-operátor kollégánk.

\section{Nyilatkozat}

A szerzők kijelentik, hogy a tanulmány megírásával kapcsolatban nem áll fenn velük szemben pénzügyi vagy egyéb lényeges összeütközés, összeférhetetlenségi ok, amelyek befolyásolhatják a tanulmányban bemutatott eredményeket, az abból levont következtetéseket vagy azok értelmezését.

\section{Irodalom}

1. Juarez-Orozco LE, Saraste A, Capodanno D, et al. Impact of a decreasing pre-test probability on the performance of diagnostic tests for coronary artery disease. Eur Heart J Cardiovasc Imaging 2019; 20: 1198-1207. DOI: 10.1093/ehjci/jez054

2. Haase $R$, Schlattmann $P$, Gueret $P$, et al. Diagnosis of obstructive coronary artery disease using computed tomography angiography in patients with stable chest pain depending on clinical probability and in clinically important subgroups: meta-analysis of individual patient data. BMJ 2019; 365: I1945. DOI: 10.1136/bmj.I1945.

3. Moss AJ, Williams MC, Newby DE, Nicol ED. The Updated NICE Guidelines: Cardiac CT as the First-Line Test for Coronary Artery Disease. Curr Cardiovasc Imaging Rep 2017; 10: 15. DOI: $10.1007 /$ s12410-017-9412-6

4. Knuuti J, Wijns W, Saraste A, et al. 2019 ESC Guidelines for the diagnosis and management of chronic coronary syndromes. Eur Heart J 2020; 41: 407-477. DOI: 10.1093/eurheartj/ehz425

5. Bartykowszki A, Kerecsen G, Jermendy ÁL, et al. A koronária-CT-angiográfia értelmezése és leletezése. A Magyar Kardiológusok Társasága Kardiovaszkuláris Képalkotó Munkacsoportjának ajánlása. Cardiologia Hungarica 2017; 47: 2-9. DOI: 10.26430/ CHUNGARICA.2017.47.1.2

6. Leipsic J, Abbara S, Achenbach S, et al. SCCT guidelines for the interpretation and reporting of coronary CT angiography: a report of the Society of Cardiovascular Computed Tomography Guidelines Committee. J Cardiovasc Comput Tomogr 2014; 8: 342-58. DOI: 10.1016/j.jcct.2014.07.003

7. Blaha MJ, Mortensen MB, Kianoush S, Tota-Maharaj R, Cainzos-Achirica M. Coronary Artery Calcium Scoring: Is It Time for a Change in Methodology? JACC Cardiovasc Imaging 2017; 10: 923937. DOI: 10.1016/j.jcct.2014.07.003

8. Lo-Kioeng-Shioe MS, Rijlaarsdam-Hermsen D, van Domburg RT et al. Prognostic value of coronary artery calcium score in symptomatic individuals: A meta-analysis of 34,000 subjects. Int J Cardiol 2020; 299: 56-62. DOI: 10.1016/j.ijcard.2019.06.003

9. Kwan AC, Cater G, Vargas J, Bluemke DA. Beyond Coronary Stenosis: Coronary Computed Tomographic Angiography for the Assessment of Atherosclerotic Plaque Burden. Curr Cardiovasc Imaging Rep 2013; 6: 89-101. DOI: 10.1007/s12410-012-9183-z

10. Vavere AL, Arbab-Zadeh A, Rochitte CE, et al. Coronary artery stenoses: accuracy of 64-detector row CT angiography in segments with mild, moderate, or severe calcification - a subanalysis of the CORE-64 trial. Radiology 2011; 261: 100-8. DOI: 10.1148/ radiol.11110537

11. Investigators SH, Newby DE, Adamson PD, et al. Coronary CT Angiography and 5-Year Risk of Myocardial Infarction. N Engl J Med 2018; 379: 924-933. DOI: 10.1056/NEJMoa1805971 